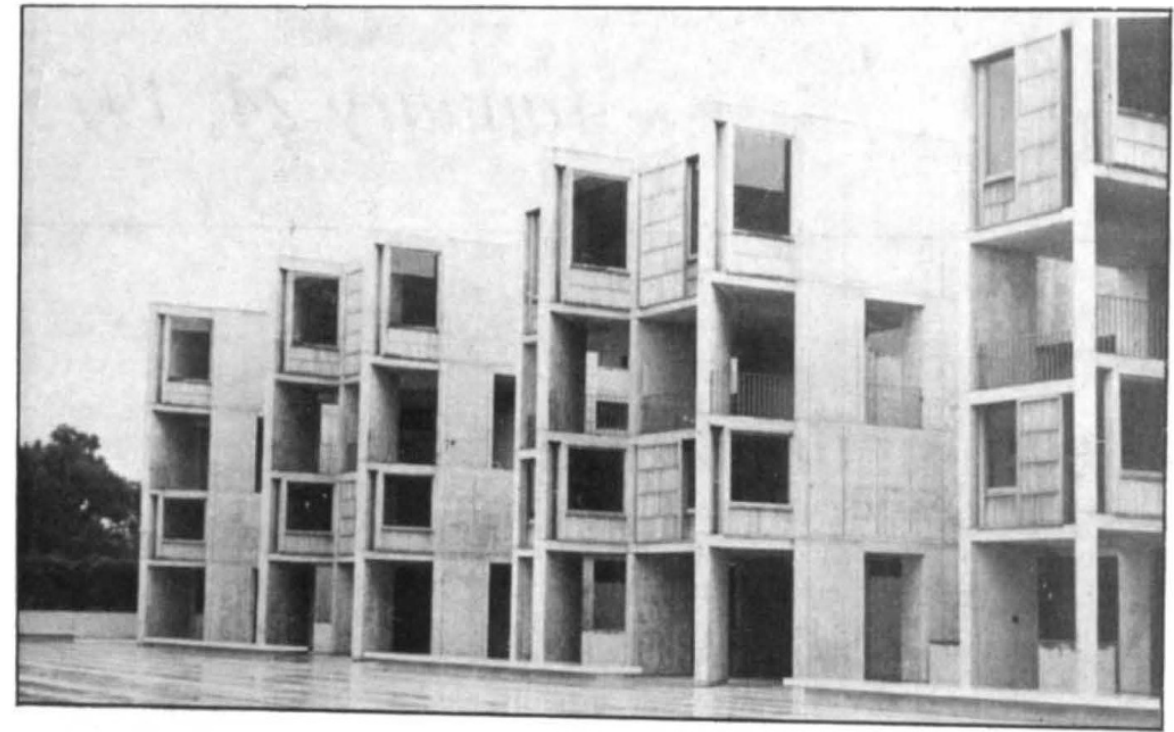

\section{Salk of human kindness}

Armed with promises of financial support, 27 acres of prime building land donated by the citizens of San Diego and a strong conviction that science should be used for the good of man, Jonas Salk, an immunologist whose name became a household word when he developed the world's first polio vaccine, began in the late 1950 s to plan a new venture. He wanted to establish a biological research centre dedicated "to contributing . . . to the health and well-being of man". The resulting Salk Institute for Biological Studies, now 11 years old, is a remarkable place. Colin Norman reports.

SET atop low cliffs overlooking the Pacific Ocean, just up the coast from the Scripps Institution of Oceanography and a stone's throw from the San Diego campus of the University of California, the institute probably ranks among the best known scientific establishments in the world. Salk's name alone is enough to ensure a good deal of publicity for the place, but it has also been pushed into the limelight through the works of one of its fellows, the late Jacob Bronowski, whose epic television series "The Ascent of Man" opened in North America this month. And, within the scientific community, the institute has already carved out a considerable reputation for itself in several areas of biomedical science.

Equally celebrated is the institute's stunning architecture. A striking concrete and glass design endowed with more than a touch of cubism, the structure is in fact so well known that the place has become something of a tourist attraction and the buildings have even been used on several occasions as a backdrop for fashion photographs. (Permission to film a battle scene in the central courtyard was, however, denied on the grounds that it would have been rather distracting for the scientists.) As well as attracting tourists and photographers, the buildings have also spawned reams of prose in publications ranging from textbooks on modern architecture to Time magazine, the prize for which must surely go to the following florid description: "A spread of related buildings (conceived) to propitiate the gods of science even as the ancient Athenians built the Acropolis to keep their gods happy".

But how does the institute propitiate the gods of science in a manner different from other, less glamorous, research establishments? Salk's intention was to create an institute where research would be devoted primarily to health problems, but he also wanted to add an extra dimension of humanism to the place to ensure that the research is indeed, devoted to enhancing the well-being of man--biology with a conscience, Salk has called it.

In several respects, the institute has turned out much as its founder intended, but the grand design has altered a little over the years-." "evolved is a better word", Salk insists-and there have recently been some significant changes in the way in which the institute operates. It has also run into its fair share of problems, not the least of which have been a chronic shortage of funds and, until recently, some discontentment among the younger researchers there.

Salk says that he first conceived the idea of founding a scientific institute in 1956, two years after his momentous development of a killed polio virus vaccine. He was assisted in the planning by a number of prominent scientists, among whom the nuclear physicist Leo Szilard is said to have been influential, and his chief supporter was Basil O'Connor, the President of the National Foundation-March of Dimes (NFMD). The project began to take concrete shape in the early $1960 \mathrm{~s}$ with the help of the architect Louis I. Kahn and financial backing from the NFMD (which also supported Salk's work on the polio vaccine), on a plot of land in the wealthy San Diego suburb of La Jolla. The first senior scientists were appointed in 1963.

The basic idea was to bring together a number of eminent scientists and give them tenure, freedom from teaching duties, a large amount of laboratory space, and it was hoped an adequate budget for their work. These so-called resident Fellows would provide overall scientific direction for the institute themselves, with the outside help of a panel of equally eminent non-resident Fellows who would meet once a year, advise on major new projects and on senior staff appointments.

The first resident Fellows reflected in large measure Salk's background in immunology and virology. Appointed in 1963 were the immunologists Melvin Cohn and Edwin Lennox, both of whom joined Salk from the Pasteur Institute, the virologist Renato Dulbecco, who moved down the coast from the California Institute of Technology (and who has since left to join the Imperial Cancer Research Fund in London, although he is still technically a resident Fellow of the Salk) and Jacob Bronowski, the mathematician, philosopher, broadcaster and humanist, who joined the Salk Institute from the British National Coal Board.

The next fellow appointed was Leslie Orgel who moved to the institute from the University of Cambridge in 1965 to continue his research into the chemical evolution of life. The Nobel Prizewinner Robert Holley came to La Jolla from Columbia University in 1968, and has since been working on the factors that control cell growth and division. And the latest senior appointment was Roger Guillemin, who moved from the Baylor College of Medicine in Houston to the Salk Institute in 1970, where he has continued his research into the control of the pituitary-work which recently led to the discovery of a new hormone produced in the hypothalamus, called somatostatin, which may bc useful in the treatment of juvenile diabetes.

A common theme among those eight resident Fellows is that most of them have broad backgrounds-a factor which Salk says was deliberately sought when the appointments were being con- 
sidered. Lennox, for example, was a nuclear physicist before he turned to immunology, Holley worked on nitrogen fixation and transfer RNA before he became interested in cell division, Orgel moved into prebiotic synthesis from inorganic chemistry, Bronowski started out as a mathematician, applied his skills to problems of evolution, developed a smokeless fuel, and was active in writing and broadcasting, and Salk has lately been engaged in writing on philosophy and ethics.

The non-resident Fellows, who meet in La Jolla in January each year to discuss the scientific affairs of the institute, include Nobel Prizewinners Jacques Monod, Gerald Edelman and Salvador Luria, and the President of MIT, Jerome Weisner. Although they play less of a role in the institute's affairs than they did during its early days, their input is still significant. Luria, for example, says that he often feels "more involved in decisions at the Salk than at MIT".

Until relatively recently, the scientific work of the Salk Institute was almost totally dominated by the research interests of its eight resident Fellows, each of whom heads a research group. In the early days, for example, much of the grant money flowing into the institute was channelled through the Fellows to members of their research group-a situation which led to some disenchantment on the part of younger scientists who wanted to pursue their own lines of research. Another cause of frustration was the fact that only the Fellows had tenured appointments; the other scientists were, in theory, less secure at the Salk than their colleagues were in the universities.

But a number of factors have recently altered both of those causes of disharmony, so that the Salk Institute now seems a relatively harmonious place to work in. Perhaps the most significant development has been the setting up of a number of independent research groups consisting mostly of younger scientists working in such fields as neurobiology, cancer, linguistics and reproductive biology. Their work is not tied to that of any of the Fellows, and according to one longstanding member of the institute, the result has been a great improvement in communications between the major research groups there. Another scientist put it more vividly: "a few years ago, nobody talked to anybody else; now the communication is excellent". One particular area which has recently benefited from such collaboration is that of cell division, where studies in three different laboratories at the Salk have recently converged to provide some clues to the factors which cause cells to grow and divide.

As for the question of tenure, last year eight members of the institute were given the title of Associate $\mathrm{Re}$ search Professor, and given conditions of tenure similar to those which pertain in the universities. For some of the younger scientists at the Salk, the fact that there is now demonstrably a career structure in the place could be an important factor in persuading them to stay there.

But the institute still has its problems. Like most centres of learning these days, it is short of funds, with the result that it has been difficult for the institute to move into major new areas of research. Another consequence is that the institute's work is now heavily concentrated in cancer research, largely because cancer money is relatively easy to come by compared with funds for other areas of science. A little over half of the institute's work is now concerned with cancer and related studies.

Salk points out, however, that since the institute is interested in "whatever seems to be in the forefront of advancing knowledge", cancer research is a natural area to be involved with, and it is also a good area for attracting bright young scientists.

The institute has also been forced recently to live much more off government funds than it used to. Last year, for example, some $\$ 4.5$ million of the $\$ 7$ million operating budget came from government grants and contracts. The rest came roughly in the form of a \$1 million grant from the National Foundation-March of Dimes, about $\$ 1$ million from other foundations, and \$0.5 million from private donations.

The financial affairs of the institute have, however, recently been placed on a firmer footing by the appointment of Frederic de Hoffmann as President and chief administrator. A nuclear physicist who worked on the Manhattan Project, de Hoffmann has, according to one Fellow of the institute, "brought a sense of financial responsibility" to the place, and he is also credited with providing the impetus for many of the recent changes such as the cstablishment of more independent research groups and the extending of tenure to scientists below the rank of Fellow.

One measure of the increased financial stability is that the institute is hoping soon to raise sufficient money to begin a major new programme in neurobiology. Because plans for several large programmes had to be shelved when funding became tight in the early 1970 s, some $35 \%$ of the laboratory space in the institute has never been occupied, and so the neurobiology programme, if it gets under way, will still leave the institute well short of its maximum capacity.

Another area in which there has been talk of expansion is the institute's human affairs programme. But that received a severe setback last August by the death from a heant attack of Jacob Bronowski, and it is yet to be determined how that side of the institute's activities will develop. Although Bronowski's work did not impinge much on the activities of most of the other scientists in the Salk Institute his range of interests clearly added an extra dimension to the place-a dimension which Salk says "will continue so long as I am here". A scientist closely connected with the institute suggested, however, that it has "never really managed to be a place where biology and the humanities were fused", chiefly because Bronowski's human affairs programme involved too few people. "A critical mass was never reached", he suggested, and there were consequently too few areas of overlap with the rest of the institute's members.

Be that as it may, the Salk Institute now seems to have entered a period of slow growth, paced chiefly by the availability of funds. After its first eleven years of evolution, it remains, in Luria's words, "overall, an exciting place",

Some of the resident and non-resident Fellows of the Salk Institute. From left to right: Jacaues Monod, Gerald Edelman. Melvin Cohn. Leslie Orgel, From left to right: Jacaues Monod, Gerald Edelman. Melvin Cohn. Leslie Orgel,
Robert Holley, the late Jacoh Bronowski, Frederic de Hoffmann, Salvador Luria, Paul Berg, Edwin Lennox and Roger Guillemin.

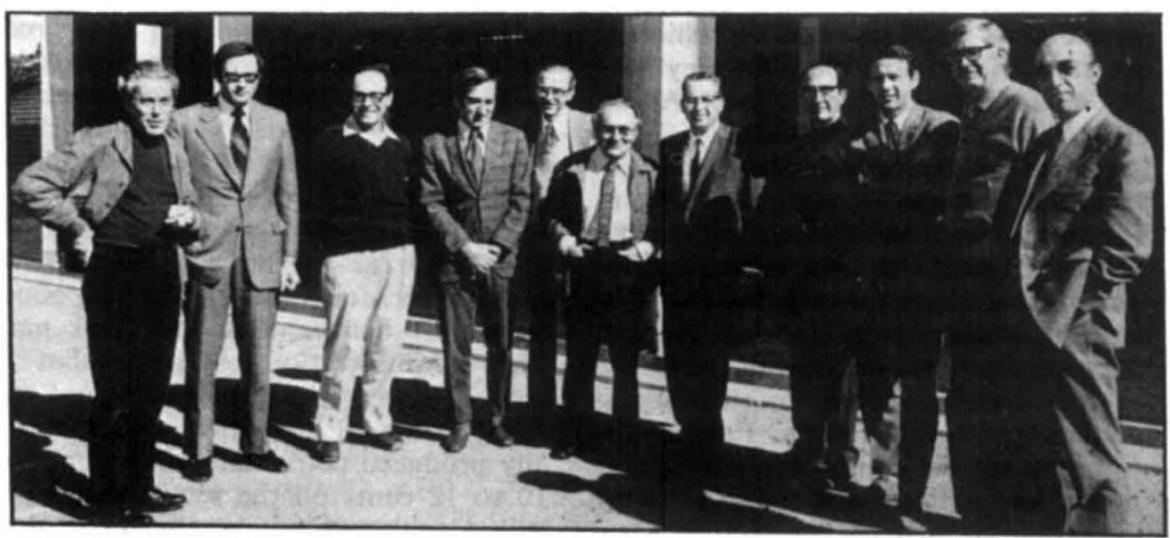

